\title{
Performance of Hybrid Chickens as Influenced by Phytogenic Extracted Meal-Supplemented Diet as Antibiotic Alternatives During Summer
}

\author{
Hayam M. A. Abo El-Maaty ${ }^{1}$, A. Y. El-Khateeb ${ }^{2}$, Asmaa Sh. El-Naggar ${ }^{3}$, Sara Kh. Sherif ${ }^{1} \&$ E. A. El-Said ${ }^{4}$ \\ ${ }^{1}$ Poultry Production Department, Faculty of Agriculture, Mansoura University, Mansoura, Egypt \\ ${ }^{2}$ Department of Agricultural Chemistry, Faculty of Agriculture, Mansoura University, Mansoura, Egypt \\ ${ }^{3}$ Department of Animal and Poultry Prod., Fac. of Agriculture, Damanhour University, Damanhour, Egypt \\ ${ }^{4}$ Poultry Production Department, Faculty of Agriculture, Damietta University, Damietta, Egypt \\ Correspondence: Hayam M. A. Abo El-Maaty, Poultry Production Department, Faculty of Agriculture, Mansoura \\ University, Mansoura, Egypt. Tel: 002-010-0896-1731. E-mail: hayam151@yahoo.com
}

Received: March 31, 2018

doi:10.5539/jas.v10n7p471

\begin{abstract}
The performance of hybrid chickens fed plant-protein diets was compared to those fed diets supplemented with Ziziphus, Jatropha, white berry, black berry and pomegranate leaves extracted meal at level of $(0.5 \mathrm{~g} / \mathrm{kg}) \mathrm{or} \mathrm{Vit}$. E. Two hundred and forty, 2 weeks-old unsexed Arbor acres chicks were used. A total number of 30 chicks were allocated for each treatment, divided into 3 replicates (10 birds/each) and housed in broiler cages. The chicks were fed the experimental grower diets from 2 to 6 weeks of age during summer season. All chicks were managed in similar fashion and had free access to feed and water throughout grower period. Measurements include were growth performance, carcass quality, digestibility and some plasma constituents.

Results obtained showed that: growth performance criteria were positively $(\mathrm{P} \leq 0.05)$ affected by dietary supplementation with Ziziphus, Jatropha, white berry, black berry and pomegranate leaves extracted meal in the diet during the whole growing period. Digestible coefficients of CP, EE, NFE and ash retention were increased significantly $(\mathrm{p} \leq 0.05)$ by dietary additions. Broilers fed the herb leaves extract-supplemented diet had significantly higher HDL, SOD, urea, ALT and creatinine levels than positive or negative control. This indicates better liver function as also appears from the normal architecture with a normal size central vein (CV) and several homogenous masses of liver cords with normal hepatocytes (h) and few fatty cirrhotic areas (f). It can be concluded that phytogenic extracted meals have a beneficial effect on growth performance and liver histology especially in summer season.
\end{abstract}

Keywords: broiler performance, blood parameters, carcass traits, phytogenic

\section{Introduction}

Feed cost is the major item in broiler production since it represents at least $65 \%$ of production cost. Dietary protein accounts for around $40 \%$ of the feeding cost of poultry (Ojewola et al., 2005). The developing countries must look for alternative cheaper feeds for maximizing the productivity of birds and promoting the quality of their products (Martínez et al., 2011).

Many feed alternatives have been examined in diets of broiler chicks. Nowadays, several feed additives are utilized for poultry of these additives, antimicrobials, antioxidants, emulsifiers, feed binders and enzymes are routinely used. The importance of these additives, especially of plant origin, has greatly increased in recent years (Abo El-Maaty et al., 2014).

According to the need to formulate healthy and safe diets for poultry, most nutritionists were turned to natural phytogenic feed additives such as herbs, spices and various plant extracts (Hamid et al., 2016; El-Bendary et al., 2016). Such feed additives are rich sources of bioactive compounds and have antimicrobial and antifungal properties (Hernandez, 2004). 
It has been reported that mulberry leaves have a cholesterol and triglyceride-lowering effect in laying hens (Panja, 2013). In addition, Shivakumar et al. (1995), and Singh and Makkar (2002) reported that mulberry is nutritious, nontoxic contain no or less tannin and phenol contents. The nutrient component of mulberry leaves include crude protein, calcium, ascorbic acid, carotene, vitamin B1, folic acid, folinic acid and vitamin D (Sarita et al., 2006).

In tropical countries, monogastric species can efficiently utilize leaves of plants and trees provided that the presence of a valid strategy in this question (Dale, 2007; Roa, 2011).

Recently, Abdulameer et al. (2017) reported that the Ziziphus spp. leaves are considered as one of the most significant feed sources due to their use as antibiotic or antiseptic and alternative medicine. Ziziphus mauritiana leaves contain many types of biological substances like lipids, protein, polyphenols, flavonoids, proanthocyanidins, alkylphenols, carboxylic acids, sterols, cyclopeptides, saponin glycoside, mucilage and free sugars. These ingredient materials are promising source to improve animal and human health status (Okoko et al., 2008). Ziziphus mauritiana was antibacterial drug against E. coli, S. pyogenes and S. aureus while Ziziphus spinachristi was very strong only against $S$. pyogenes (Abalaka et al., 2010). In vitro and in vivo, the antimicrobial and anti-fungi effects of the Ziziphus leaves extract were also studied (Hassan et al., 2017).

Jatropha carcus can be used as feed additive in both human and animal nutrition as vegetable because of its medical (antimicrobial and anti-inflammatory property) and nutritive composition in the leaf and stem bark (Atamgba et al., 2015), they also express anti-proliferative and antimicrobial actions while some species such as Jatropha euphorbia possess anti-tumor and anti-cancer activity. The antiproliferative and antimicrobial activities of the leaf help to regulate the amount of harmful micro-organism in the gut thereby increasing the rate of feed nutrient absorption into the body for maximum feed efficiency (Odoemelam et al., 2013).

In a later study, Adeyemo and Oluyede (2015) who showed that Jatropha curcas as a phytogenic plant assumes a significant part in the treatment of different disease infections. It holds some chemical substances for example volatile oils, alkaloids, glycosides, gums, phlobatannins, tannins, steroids, saponins, and flavonoids, also required been showed to have no adverse impact on performance of chicks

Pomegranate has many bioactive components such as polyphenols, ellagitannins, vitamins, minerals and polyunsaturated fatty acids (Gil et al., 2000; Seeram et al., 2005). In particular, byproducts of pomegranate have antioxidant, anti-carcinogenic and antimicrobial properties (Reddy et al., 2007). Besides the beneficial properties, there are some limitations on the use of pomegranate byproducts in animal nutrition. Relatively high level of tannin contents in pomegranate byproducts acts as antinutritional factor in animal nutrition (Serrano et al., 2009). However, antinutritional factors like tannins could be minimized through processing such as fermentation (Dei et al., 2008).

Added dietary vitamin $\mathrm{E}$ has a positive effect on the immunocompetence of broiler chickens (Erf et al., 1998). Lipid oxidation greatly affects on the preservation of meat and thus it is a major determinant of its shelf life (Morrissey et al., 1994). Vitamin E is believed to lower fatty acyl hydroxyperoxy radicals to yield less reactive hydroperoxides (Perez et al., 2010). Tocopherols may improve the health status of broilers via preventing cancer and coronary diseases (Knekt et al., 1991). Dietary tocopherols were found to enhance the reproductive efficiency and antioxidant properties of breeder hens (Lin et al., 2005a, 2005b).

This study set out to evaluate the use of some leaves extracts of medicinal plants as antioxidant and as means to compate the adverse influence of thermal distress on the productive traits of broiler chicks.

\section{Materials and Methods}

The current study was carried out at the Poultry Research Unit, Qalabsho Center of Agricultural Researches and Experiments, Faculty of Agriculture, Mansoura University, Egypt during summer. The specific objective of this research are to investigate the effect of including Ziziphus, Jatropha, white berry, black berry and pomegranate leaves extracted meal in low plant protein broilers rations on their productivity, digestibility coefficient, carcass traits; plasma biochemistry and liver histology.

\subsection{Experimental Diets}

A Grower diet based on yellow corn, soybean meal and corn gluten meal were use to ensure suitable intake of different nutrients that recommended according to NRC (1994), growing periods. Dietary formulations, calculated and chemical analysis of the experimental diets are presented in Table 1. Positive control diet containing $20 \%$ CP, negative control diet containing $18 \%$, the Jujube, Jatropha, white berry, black berry and pomegranate meal were added to the negative control diet $(18 \% \mathrm{CP})$ by $0.5 \mathrm{~g} / \mathrm{kg}$ diets and Vit. E by $200 \mathrm{mg} \mathrm{kg}$. 


\subsection{Photochemistry of Investigated Plants}

Samples were conveyed directly to the laboratory of Agricultural chemistry at Faculty of Agriculture, Mansoura University, Mansoura, Egypt.

Plants leaves were air dried in the shade and ground into a fine powder. The Powdered air dried sample from each plant species $(1 \mathrm{Kg})$ were extracted by soaking for six times with methanol $(10 \mathrm{~L})$ at room temperature. The methanolic extracts of all plants were concentrated nearly to dryness under reduced pressure by using the rotary evaporator at $45^{\circ} \mathrm{C}$ to achieve the crude methanolic extracts which kept for further investigation. Plants are rich in polyphenolic compounds such as terpenes, tannins, flavonoids, saponins, alkaloids, glucosides and resins which have several biologically active constituents. But differ in both types and concentrations of these compounds.

\subsection{Birds and Management}

Two hundred and forty 2-week-old unsexed Arbor Acres broiler chicks were randomly distributed to eight groups, each with three equal replications. Each replication was housed in a compartment of battery cages. Chicks were fed on a basal starter diet $[23 \% \mathrm{CP}$ and ME of $3100 \mathrm{kcal} / \mathrm{kg}]$ from one to two weeks of age. Then, they were transferred to respective experimental grower diets $(20$ or $18 \% \mathrm{CP} \%$ and $\mathrm{ME}$ of $3000 \mathrm{kcal} / \mathrm{kg}$ ) up to 6 weeks of age. All birds had free access to feed and water. Chicks were subjected to similar management, hygiene and environmental conditions. The range means of surrounded temperature and relative humidity dominated during investigation on time were 21.8 to $35.5{ }^{\circ} \mathrm{C}$ and 30 to $96 \%$, respectively.

\subsection{Criteria of Response}

Chicks were weighed at the start of experiment ( 2 weeks old) and their live body weights (LBW) and feed intake (FI) were estimated weekly for each replication; thus, their body weight gain (BWG) and feed conversion (FC) were calculated.

At an age of five weeks of age, eight biological assays were made for three consecutive days. Feed intake and droppings voided for each replicate group were quantitatively determined. Samples of excreta were collected, with greatest care, then toughly mixed, dried and stored for later determinations. The experimental diets and dried droppings were chemically analyzed by the AOAC (2000).

Digestibility coefficients of nutrients and ash retention of the tested diets were computed. At 6 weeks of age, six birds per treatment were randomly selected, weighed (after a 12-hr-feed withdrawal). Broilers were sacrificed according to the ethics of animal rights and welfare applied in Mansoura University. Carcasses were immediately feathers removed and reweighed. Then, the eviscerated carcasses were individually weighed. The weights of individual edible organs (giblets) and the front and hind parts of the carcass were also estimated. The relative weights of carcass yield and edible organs were expressed as a percentage of live body weight at slaughter.

Six blood samples were collected during slaughtering in heparinized tubes. Plasma was separated by centrifugation at $4000 \mathrm{rpm}$ for 10 minutes and stored rapidly at $-20{ }^{\circ} \mathrm{C}$ until analysis. Blood plasma concentrations of creatinine, urea, Malondialdehyde (MDA), Superoxide (SOD), Glutathione (GSH), Total cholesterol, Triglycerides (TG), HDL-cholesterol, LDL-cholesterol, vLDL-cholesterol and activity of alanine aminotransferase (ALT) and aspartate aminotransferase (AST) were determined by methods of Bartles et al. (1972), Patton and Crouch (1977), Conti et al. (1991), Sun et al. (1988), Beutler et al. (1963), Richmond (1973), and Reitman and Frankel (1957).

The Statistical Analysis System (SAS, 2006) was used in the processing of the data obtained. Significant differences among means of variables were separated by using the Duncan's new multiple range test (Duncan, $1955)$ at a probability level of 0.05 . 
Table 1. Dietary formulations and calculated $\&$ chemical analysis of the experimental diets

\begin{tabular}{|c|c|c|}
\hline Ingredient (\%) & $20 \%$ CP Diet & $18 \%$ CP Diet \\
\hline Yellow corn & 62.3 & 67.25 \\
\hline Soybean meal $44 \% \mathrm{CP}$ & 29.0 & 25.50 \\
\hline Corn gluten meal $60 \% \mathrm{CP}$ & 3.00 & 1.50 \\
\hline Sunflower oil & 1.80 & 1.80 \\
\hline Dicalcium phosphate & 1.50 & 1.50 \\
\hline Ground limestone & 1.60 & 1.60 \\
\hline Common salt $(\mathrm{NaCl})$ & 0.30 & 0.30 \\
\hline Vit. \& min. premix ${ }^{\S}$ & 0.30 & 0.30 \\
\hline DL-Methionine & 0.10 & 0.10 \\
\hline L-Lysine $\mathrm{HCl}$ & 0.10 & 0.15 \\
\hline Total & 100 & 100 \\
\hline \multicolumn{3}{|c|}{ Calculated analysis (NRC, 1994) } \\
\hline $\mathrm{ME}(\mathrm{kcal} / \mathrm{kg})$ & 3026 & 3060 \\
\hline Crude protein $(\%)$ & 20.07 & 18.06 \\
\hline Calcium (\%) & 1.02 & 1.01 \\
\hline Available phosphorus (\%) & 0.41 & 0.41 \\
\hline Lysine $(\%)$ & 1.05 & 0.99 \\
\hline Methionine (\%) & 0.43 & 0.40 \\
\hline Methionine + Cystine (\%) & 0.77 & 0.71 \\
\hline \multicolumn{3}{|c|}{ Determined analysis (AOAC, 1995) } \\
\hline $\mathrm{DM}(\%)$ & 89.37 & 88.89 \\
\hline $\mathrm{OM}(\%)$ & 80.46 & 79.98 \\
\hline $\mathrm{CP}(\%)$ & 20.35 & 18.24 \\
\hline $\mathrm{EE}(\%)$ & 4.47 & 4.59 \\
\hline CF $(\%)$ & 3.44 & 3.28 \\
\hline Ash $(\%)$ & 9.02 & 8.41 \\
\hline NFE $(\%)$ & 62.72 & 65.48 \\
\hline
\end{tabular}

Note. ${ }^{\S}$ : Premix at $0.30 \%$ of the diet supplies the following/kg diet: Vit. A, 1000 IU; Vit. $\mathrm{D}_{3}, 2000$ IU; Vit. E, 10 mg; Vit. K, $1 \mathrm{mg}$; Vit. $\mathrm{B}_{1}, 5 \mathrm{mg}$; Vit. $\mathrm{B}_{2}, 5 \mathrm{mg}$; Vit. $\mathrm{B}_{6}, 1.5 \mathrm{mg}$; Vit. $\mathrm{B}_{12}, 0.01 \mathrm{mg}$; Folic acid, $0.35 \mathrm{mg}$; Biotin, $0.05 \mathrm{mg}$; Pantothenic acid, $10 \mathrm{mg}$; Niacin, $30 \mathrm{mg}$; Choline chloride, $250 \mathrm{mg}$; Fe, $30 \mathrm{mg}$; Zn, $50 \mathrm{mg}$; Cu, $4 \mathrm{mg}$ and $\mathrm{Se}, 0.1 \mathrm{mg}$.

\section{Results and Discussion}

\subsection{Growth Performance}

Phytogenic feed additives have been wildly used similarly as an elective looking into antibiotics because of their plant derived property additionally growth-promoting affects (Ao et al., 2011). Data founded in Table 2 reported the effect of dietary supplementation with Ziziphus, Jatropha, white berry, black berry and pomegranate leaves extracted meal or Vit. E on live body weight (BW), Body weight gain (BWG), feed intake (FI) and feed conversion (FC) of broiler chicks.

Live body weight (BW), Body weight gain (BWG), feed intake (FI) and feed conversion ratio (FCR) were significantly $(\mathrm{P} \leq 0.05)$ affected by dietary supplementation with Ziziphus, Jatropha, white berry, black berry and pomegranate leaves extracted meal in the diet during the whole growing period. Chick fed diet supplemented with white berry leaves extracted meal had higher live body weight (2967 g), body weight gain ( $2345 \mathrm{~g})$ at 6 weeks of age, and better feed conversion ratio $(1.72 \mathrm{~g} / \mathrm{g})$, followed by those fed diet supplemented with black berry, Jatropha, pomegranate and Ziziphus leaves extracted meal compared with those fed vit. E-supplemented diet or basal diet (containing $20 \% \mathrm{CP}$ or $18 \% \mathrm{CP}$ ). The lowest Body weight was recorded in group fed low protein diet (containing 18\% CP) without any feed additives, followed by those fed the positive control diet (containing $20 \%$ $\mathrm{CP}$ ). Adding of medicinal plant leaves extracted meal could be useful as an alternative to antibiotics, chemical antioxidant, chemical antifungal, chemical anti-heat stress and chemical growth promoter because of its positive effects on BW, BWG, FI and FCR. There are improvements in feed conversion ratio of treatments fed medicinal 
plant leaves extracted meal-supplemented diet in spite the low rate of feed consumption may be due to the effect of phytogenic bioactive substances on digestion and reducing oxidative damage. This was in agreement those reviewed by (Adeyemo \& Oluyede, 2015) who reported that some plant extracts might invigorate the secretion of saliva, gastric and pancreatic juice favoring the secretion of enzymes and therefore improving digestibility coefficients.

It is known that the significant effects of the herbal plants are more effective as antibiotic alternative and antioxidant materials (Sharifi et al., 2013) and their activating influence on the alimentary tract of broilers (Langhout, 2000). Additionally, the data are harmony with (Son, 2014; Abdulameer et al., 2017) who found that using of Ziziphus jujuba as a feed additive had increased the growth of broiler chickens. In accordance with our results, Johnson et al. (2013), who reported that an enhancement in final body weight, BWG, FI and FCR in Jatropha leaves fed broiler chicks which have a beneficial effect on health and immune status of the chicks. They also stated that Jatropha leaves might have a detectable quantity of minerals for body health and homeostasis and other metabolic functions while their moderate contents of crude fiber will improve the rate of feed passage within the digestive tract.

Table 2. Impact of dietary supplementation with Ziziphus, Jatropha, white berry, black berry and pomegranate meal or Vit. E on growth performance of broiler chicks from 14 to 42-days-old of age

\begin{tabular}{llllll}
\hline Dietary Treatments & $\begin{array}{l}\text { Initial weight } \\
(\mathrm{g})\end{array}$ & $\begin{array}{l}\text { Final body weight } \\
(6 \mathrm{wk})(\mathrm{g})\end{array}$ & $\begin{array}{l}\text { Gain } \\
(\mathrm{g} / \mathrm{bird})\end{array}$ & $\begin{array}{l}\text { Feed intake } \\
(\mathrm{g} / \mathrm{b} \text { ird })\end{array}$ & $\begin{array}{l}\text { Feed conversion ratio } \\
(\mathrm{g} / \mathrm{g})\end{array}$ \\
\hline Control(+) & 621 & $2706^{\mathrm{b}}$ & $2085^{\mathrm{b}}$ & $4208^{\mathrm{a}}$ & $2.02^{\mathrm{c}}$ \\
Control (-) & 621 & $2341^{\mathrm{c}}$ & $1719^{\mathrm{c}}$ & $4193^{\mathrm{a}}$ & $2.44^{\mathrm{c}}$ \\
Ziziphus & 620 & $2742^{\mathrm{ab}}$ & $2121^{\mathrm{ab}}$ & $3892^{\mathrm{b}}$ & $1.83^{\mathrm{b}}$ \\
Jatropha & 620 & $2767^{\mathrm{a}}$ & $2146^{\mathrm{a}}$ & $3852^{\mathrm{b}}$ & $1.79^{\mathrm{a}}$ \\
$\quad$ White berry & 621 & $2967^{\mathrm{a}}$ & $2345^{\mathrm{a}}$ & $4030^{\mathrm{ab}}$ & $1.72^{\mathrm{a}}$ \\
$\quad 622$ & $2781^{\mathrm{a}}$ & $2158^{\mathrm{a}}$ & $3894^{\mathrm{b}}$ & $1.80^{\mathrm{b}}$ \\
$\quad$ Black berry & 620 & $2753^{\mathrm{ab}}$ & $2132^{\mathrm{ab}}$ & $3845^{\mathrm{b}}$ & $1.80^{\mathrm{b}}$ \\
Pomegranate & 651 & $2712^{\mathrm{b}}$ & $2060^{\mathrm{b}}$ & $3855^{\mathrm{b}}$ & $1.87^{\mathrm{b}}$ \\
Vitamin E & 2.76 & 9.26 & 9.97 & 33.88 & 0.085 \\
SEM & $\mathrm{NS}$ & $*$ & $*$ & $*$ & $*$ \\
Prop. & $* 26$ & & $* 87$
\end{tabular}

Note. Means with the same letter are not significantly different $(\mathrm{P} \leq 0.05)$.

T1: control (+), T1: control (-), T3: Ziziphus, T4: Jatropha, T5: white berry, T6: black berry, T7: pomegranate leaves extracted meal by $0.50 \mathrm{~g} / \mathrm{kg}$, and T8: Vit. E $0.20 \mathrm{~g} / \mathrm{kg}$

The significant enhancement in body weight of chicks fed berry leaves extracts is in concurrence with the findings of Biswas et al. (2011), who showed that natural antioxidants were effective in improving body weight gain in chicks. Moreover, with the findings of (Rezaeipour et al., 2011) who reported a linearly improved of feed conversion ratio with increase of antioxidant ( $\alpha$-Tocopheryl) in the diet of broilers. Arshad et al. (2013) had also reported that antioxidant ( $\alpha$-lipoic acid)-supplemented diets had significant variation on the body weight and feed conversion ratio of broilers. Total body weight gain was more in supplemented treatment, this increase in body weight may be because of its properties like increase protein utilization, rich protein source and have immunomodulatory properties (Khan et al., 2005). Additionally the positive effect on LBW, BWG, FCR due to feeding mulberry supplemented diet a good source of protein for animals (Wang et al., 2017). But improvement of FCR might be stimulating digestive enzymes followed by better digestion and utilization of feed. It is realized that high fiber content decreased feed consumed in broilers (Islam et al., 2014), yet the better amino acid composition in mulberry (Al-Kirshi et al., 2010) could have recompensed for this impact. Addition their effect extensively scavenging effect on oxygen radicals in vivo and vitro because of their naturally flavonoids effects (Seyoum et al., 2006). Saleh et al. (2017) who found that broiler fed pomegranate supplemented-diet, which contained natural antioxidant, had enhanced feed efficiency. The growth promoting effect of herbs was previously reported to enhance final body weight, WG and FCR of broiler chicks (Ibrahim et al., 1998). Siegel et al. (2001) who observed that chicks fed vitamin E supplemented-diet had greater BW gains compared with the control one. On the other hand, Bartov and Frigg (1992) who reported that BW gain was not significantly affected by dietary supplementation of vitamin E in broiler chicks. Moreover, chickens fed $\alpha$-Toc-supplemented diet had no significantly enhanced growth performance contrasted with the control group (Saleh et al., 2017). 
Vasanthakumar et al. (2013) founded that broiler fed supplementation of tulsi powder $(0.5 \%)$ and commercial grade tulsi extract $(0.1 \%)$ in the diet enhances the overall performance, antioxidant status and immunity in commercial broiler chickens during summer.

\subsection{Nutrient Digestibility}

The results of nutrient digestibility and rate of ash retention (\%) are founded in Table 3. The digestibilities of DM, $\mathrm{OM}$ and $\mathrm{CF}$ were not affected by dietary treatments. But digestible coefficients of CP, EE, NFE and ash retention were increased significantly $(\mathrm{p} \leq 0.05)$ by dietary treatments. In the present study, using Ziziphus, Jatropha, white or black berry and pomegranate dried leaves extracted meal or Vit. E in diets of broiler chicks had a positive effect on $\mathrm{CP}, \mathrm{EE}, \mathrm{NFE}$ and ash retention digestible coefficients.

Table 3. Effects of Ziziphus, Jatropha, white or black berry and pomegranate dried leaves extracted meal or Vit. E as feed additives in hybrid chicks diet on nutrient digestibility and ash retention

\begin{tabular}{llllllll}
\hline Treatments & DM (\%) & OM & CP (\%) & CF (\%) & EE (\%) & NFE (\%) & Ash retention (\%) \\
\hline Control (20\% CP) & 77.82 & 78.09 & $77.55^{\mathrm{b}}$ & 24.56 & $75.78^{\mathrm{b}}$ & $76.06^{\mathrm{b}}$ & $78.56^{\mathrm{b}}$ \\
Control (18\% CP) & 77.66 & 78.06 & $76.86^{\mathrm{b}}$ & 24.42 & $74.92^{\mathrm{c}}$ & $76.02^{\mathrm{b}}$ & $78.49^{\mathrm{b}}$ \\
Ziziphus & 78.45 & 78.12 & $80.12^{\mathrm{a}}$ & 24.81 & $79.83^{\mathrm{a}}$ & $77.98^{\mathrm{a}}$ & $80.78^{\mathrm{a}}$ \\
Jatropha & 78.33 & 78.92 & $80.92^{\mathrm{a}}$ & 24.14 & $79.64^{\mathrm{a}}$ & $77.13^{\mathrm{a}}$ & $80.88^{\mathrm{a}}$ \\
$\quad$ White berry & 78.64 & 79.32 & $80.32^{\mathrm{a}}$ & 24.75 & $80.93^{\mathrm{a}}$ & $77.70^{\mathrm{a}}$ & $81.30^{\mathrm{a}}$ \\
$\quad$ Black berry & 78.01 & 79.48 & $80.48^{\mathrm{a}}$ & 24.20 & $79.30^{\mathrm{a}}$ & $77.33^{\mathrm{a}}$ & $80.91^{\mathrm{a}}$ \\
$\quad$ Pomegranate & 78.29 & 79.05 & $80.05^{\mathrm{a}}$ & 24.51 & $80.07^{\mathrm{a}}$ & $77.53^{\mathrm{a}}$ & $80.85^{\mathrm{a}}$ \\
Vitamin E & 78.09 & 78.99 & $79.89^{\mathrm{a}}$ & 24.47 & $79.54^{\mathrm{a}}$ & $76.53^{\mathrm{ab}}$ & $79.31^{\mathrm{ab}}$ \\
SEM & 0.211 & 0.225 & 0.293 & 0.651 & 0.553 & 0.223 & 0.231 \\
Prop. & NS & NS & $* *$ & NS & $*$ & $*$ & $*$ \\
\hline
\end{tabular}

Note. Means with the same letter are not significantly different $(\mathrm{P} \leq 0.05)$.

T1: control (+), T1: control (-), T3: Ziziphus, T4: Jatropha, T5: white berry, T6: black berry, T7: pomegranate leaves extracted meal by $0.50 \mathrm{~g} / \mathrm{kg}$, and T8: Vit. E $0.20 \mathrm{~g} / \mathrm{kg}$.

The observed improvement in digestibility of CP, EE, NFE and ash retention due to feeding the tested materials diets might be related to stimulation the secretion of digestive enzymes and thus increasing digestion and absorption of nutrients, particularly CP, EE, NFE and ash retention.

It should be noted that broiler chicks fed $18 \%$ CP-diets supplemented with Ziziphus, Jatropha, white or black berry and pomegranate dried leaves extracted meal showed significantly better CP, EE, NFE and ash retention digestibility compared with those fed the positive or negative control diets $(20$ or $18 \% \mathrm{CP})$ without supplementation. Such improvement in CP, EE, NFE and ash retention digestibility mirrored the enhancement in growth performance of chicks (Table 2).

Our reported data are harmonize with Son (2014) who showed that the using of Ziziphus jujuba seed meal as feed additives in chicks diet with 0.3 to $0.6 \%$ had enhanced digestibility of nutrient and reduced the NH3 emissions from feces.

The presence of some substances in plants such as alkaloids, glycosides, volatile oils, gums, tannins, steroids, saponins, phlobatannins, flavonoids and a host of other chemical compounds referred to as secondary metabolites (Adeyemo \& Oluyede, 2015). the effect of plant bioactive on digestion as this was in agreement with the work of (Adeyemo \& Oluyede, 2015) who believes that some plant extract may stimulate the production of saliva and of gastric and pancreatic juice favoring the secretion of enzymes and therefore enhancing nutrient digestibility.

\subsection{Carcass Traits}

The effects of level of dietary supplementation on broiler performance are summarized in Table 4 there were no significant differences between treatments due to added dietary supplementation. Results indicated that giblets percentage were increased significantly $(\mathrm{p} \leq 0.05)$ by treatments.

The final body weight, and total giblets weight for birds at the end of the experiment had varied significantly ( $\mathrm{p} \leq$ $0.05)$ differences. The average dressed weight of the birds at the end of the experiment no significant $(\mathrm{p} \leq 0.05)$ difference across the treatment. The carcass and organ parts were expressed as the percentage of the dressed 
weight. The values obtained for relative carcass weight, edible parts, front part and hind part were not affected by the addition of different supplementation across the treatment. In contrast to our study, no differences were observed in the internal organs. These findings provide further support for the hypothesis that the Ziziphus did not have any deleterious effect on internal organs. Thus, this study raises the possibility for the use of Ziziphus as an antibiotic alternative without any side effects. The current paper is in consistent with Abdulameer et al. (2017) finding which showed no effects of Ziziphus extract on internal organ except gizzard. It is thought that the Ziziphus extract did not have any toxic effects on the tissues (Cai \&Ramanatha, 2012). Because of the toxic effects of some herbal plants and to avoid any drawback in the treatment with Ziziphus. Moreover, there was no significant difference from the weight of the heart and liver of the animals when compared with the control treatment or due to the medicinal effect of Jatropha leaf meal which coincide with the result of Hasso (2009). In addition, values for liver, gizzard, heart and spleen did not differ significantly. This development showed there were reduced concentration of anti-nutritional factors and leaf extract of Mulberry and Jatropha in diets fed to the birds. This is because higher physiological values in organs and are stimulated by the presence of anti-nutritional factors and other harmful secondary metabolites (George et al., 2016).

Table 4. Effects of Ziziphus, Jatropha, white or black berry and pomegranate dried leaves extracted meal or Vit. E as feed additives in hybrid chicks diet on carcass traits

\begin{tabular}{lllllllll}
\hline Treatments & LBW (g) & Carcass (\%) & Liver (\%) & Gizzard (\%) & Heart (\%) & T. edible part & Front part (\%) & Hind part (\%) \\
\hline Control(+) & $2253^{\mathrm{c}}$ & 70.70 & $2.07^{\mathrm{e}}$ & $2.00^{\mathrm{a}}$ & $0.553^{\mathrm{bc}}$ & 75.32 & 41.55 & 29.15 \\
Control(-) & $2168^{\mathrm{d}}$ & 70.12 & $2.03^{\mathrm{e}}$ & $1.98^{\mathrm{a}}$ & $0.512^{\mathrm{c}}$ & 74.62 & 41.45 & 28.67 \\
Ziziphus & $2783^{\mathrm{ab}}$ & 70.71 & $2.26^{\mathrm{d}}$ & $1.76^{\mathrm{b}}$ & $0.591^{\mathrm{ab}}$ & 75.32 & 41.54 & 29.17 \\
Jatropha & $2848^{\mathrm{a}}$ & 70.72 & $2.72^{\mathrm{a}}$ & $1.68^{\mathrm{b}}$ & $0.613^{\mathrm{a}}$ & 75.73 & 41.66 & 29.06 \\
$\quad$ White berry & $2966^{\mathrm{a}}$ & 70.73 & $2.33^{\mathrm{c}}$ & $1.82^{\mathrm{b}}$ & $0.606^{\mathrm{a}}$ & 75.48 & 41.55 & 29.18 \\
$\quad$ Black berry & $2795^{\mathrm{ab}}$ & 70.70 & $2.48^{\mathrm{b}}$ & $1.68^{\mathrm{b}}$ & $0.555^{\mathrm{bc}}$ & 75.41 & 41.54 & 29.16 \\
$\quad$ Pomegranate & $2540^{\mathrm{b}}$ & 70.70 & $2.43^{\mathrm{b}}$ & $1.85^{\mathrm{ab}}$ & $0.528^{\mathrm{c}}$ & 75.51 & 41.55 & 29.15 \\
Vitamin E & $2712^{\mathrm{ab}}$ & 70.51 & $2.43^{\mathrm{b}}$ & $1.73^{\mathrm{b}}$ & $0.527^{\mathrm{c}}$ & 75.19 & 41.59 & 28.92 \\
SEM & 9.44 & 0.603 & 0.072 & 0.058 & 0.016 & 0.901 & 0.603 & 0.005 \\
Prop. & $*$ & $\mathrm{NS}$ & $*$ & $*$ & $*$ & $\mathrm{NS}$ & $\mathrm{NS}$ & $\mathrm{NS}$ \\
\hline
\end{tabular}

Note. Means with the same letter are not significantly different $(\mathrm{P} \leq 0.05)$.

T1: control (+), T1: control (-), T3: Ziziphus, T4: Jatropha, T5: white berry, T6: black berry, T7: pomegranate leaves extracted meal by $0.50 \mathrm{~g} / \mathrm{kg}$, and T8: Vit. E $0.20 \mathrm{~g} / \mathrm{kg}$.

\subsection{Blood Parameters}

The effect of different dietary supplementations (Ziziphus, Jatropha, white and black berry and pomegranate) on blood cholesterol, triglycerides (TG), HDL, LDL, SOD, GSH, MDA, urea, creatinine and liver function (AST, ALT) concentrations are summarized in Table 5. There were no significant effect of different dietary supplementations on plasma GSH in all groups during the experimental period whereas, broilers fed phytogenic-supplemented had significantly higher HDL, SOD, urea, ALT and creatinine levels than negative group.

On the other hand, MDA, AST, cholesterol, triglycerides and LDL were significantly decreased in all experimental groups especially white berry-supplemented group. Our values are in accordance with studies which reported that mulberry treatment significantly decreased blood urine, LDL, VLDL-cholesterol and triglycerides secretion and decreased triglycerides synthesis from chick hepatocyte compared to the control groups (Mohebbi et al., 2007). It appears that Mulberry active compound had a positive effect on cholesterol, TG and LDL which regulate the metabolic activity of lipids, while at the same time increasing HDL cholesterol (Abd El-Hady et al., 2017). Besides the effective compounds of mulberry leaves they are nontoxic and have natural therapeutic properties because they act as antioxidants, anti-stress agents and immunoenhancers, and have cholesterol-lowering and nephro- and hepato-protective properties (Yang et al., 2012; Devi et al., 2013). Numerous researches demonstrated that anthocyanins and flavonoids present in mulberry leaves can protect against atherosclerotic and coronary heart diseases via removing the metabolic free radicals, inhibiting the LDL oxidation and their hypolipidemic and hypocholesterolemic properties (Zeni \& Molin, 2010; Valacchi et al., 2014). Also, Abd El-Hady et al. (2017) who observed that decreased blood malondialdehyde and increased glutathione levels as Glutathione boosts white 
blood cell production particularly lymphocytes, meanwhile, mulberry treatments had higher significant effect on creatinine levels.

In the same trend, the MDA production was significantly reduced by the inclusion of vitamin E, applied here, compared with the control birds. These results coincide with those reported by Englmaierová et al. (2011). Sahin et al. (2006), who observed an increase in blood plasma HDL concentration and a reduction in LDL concentration in Japanese quail fed lycopene supplemented-diet as a source of vit. E.

Table 5. Effects of Ziziphus, Jatropha, white or black berry and pomegranate dried leaves extracted meal or Vit. E as feed additives in hybrid chicks diet on blood parameters

\begin{tabular}{|c|c|c|c|c|c|c|c|c|c|c|c|c|}
\hline Dietary Treatments & $\begin{array}{l}\text { ALT } \\
(\mathrm{IU} / \mathrm{L})\end{array}$ & $\begin{array}{l}\text { AST } \\
\text { (IU/L) }\end{array}$ & $\begin{array}{l}\text { Creatinin } \\
(\mathrm{mg} / \mathrm{dl})\end{array}$ & $\begin{array}{l}\text { Urea } \\
(\mathrm{mg} / \mathrm{dl})\end{array}$ & $\begin{array}{l}\text { MDA } \\
(\mu \mathrm{mol} / \mathrm{ml})\end{array}$ & $\begin{array}{l}\text { SOD } \\
(\mathrm{U} / \mathrm{ml})\end{array}$ & $\begin{array}{l}\text { GSH } \\
(\mu \mathrm{mol} / \mathrm{ml})\end{array}$ & $\begin{array}{l}\text { Choles } \\
(\mathrm{mg} / \mathrm{dl})\end{array}$ & $\begin{array}{l}\text { Triglycr } \\
(\mathrm{mg} / \mathrm{dl})\end{array}$ & $\begin{array}{l}\mathrm{HDL} \\
(\mathrm{mg} / \mathrm{dl})\end{array}$ & $\begin{array}{l}\text { LDL } \\
(\mathrm{mg} / \mathrm{dl})\end{array}$ & $\begin{array}{l}\text { vLDL } \\
(\mathrm{mg} / \mathrm{dl})\end{array}$ \\
\hline Control(+) & $8.00^{\circ}$ & $201.3^{\mathrm{a}}$ & $0.267^{\mathrm{c}}$ & $51.67^{\mathrm{ed}}$ & $8.05^{\mathrm{a}}$ & $14.03^{\mathrm{c}}$ & 22.63 & $113.0^{\mathrm{a}}$ & $98.33^{b}$ & $31.00^{b}$ & $62.33^{\mathrm{a}}$ & $19.67^{b}$ \\
\hline Control (-) & $5.67^{d}$ & $202.7^{\mathrm{a}}$ & $0.267^{\mathrm{c}}$ & $49.33^{\mathrm{e}}$ & $8.03^{\mathrm{a}}$ & $12.57^{\mathrm{d}}$ & 21.57 & $114.2^{\mathrm{a}}$ & $93.67^{c}$ & $36.00^{\mathrm{a}}$ & $59.47^{\mathrm{ab}}$ & $18.73^{\mathrm{c}}$ \\
\hline Ziziphus & $11.30^{\mathrm{b}}$ & $198.3^{\mathrm{a}}$ & $0.533^{\mathrm{a}}$ & $57.85^{\mathrm{b}}$ & $8.13^{\mathrm{a}}$ & $22.80^{\mathrm{a}}$ & 25.32 & $104.7^{\mathrm{bc}}$ & $102.33^{\mathrm{a}}$ & $31.67^{b}$ & $52.57^{b}$ & $20.46^{\mathrm{a}}$ \\
\hline Jatropha & $19.67^{\mathrm{a}}$ & $154.3^{\mathrm{c}}$ & $0.433^{\mathrm{a}}$ & $67.67^{\mathrm{a}}$ & $2.77^{\mathrm{d}}$ & $18.83^{b}$ & 25.10 & $113.0^{\mathrm{a}}$ & $97.67^{b}$ & $30.33^{c}$ & $63.14^{\mathrm{a}}$ & $19.53^{b}$ \\
\hline White berry & $18.00^{\mathrm{a}}$ & $117.7^{\mathrm{d}}$ & $0.367^{\mathrm{b}}$ & $61.00^{\mathrm{b}}$ & $2.50^{\mathrm{d}}$ & $19.99^{\mathrm{ab}}$ & 24.30 & $109.0^{\mathrm{ab}}$ & $89.00^{\mathrm{d}}$ & $35.33^{\mathrm{a}}$ & $55.87^{\mathrm{ab}}$ & $17.80^{\mathrm{d}}$ \\
\hline Black berry & $9.67^{b c}$ & $191.0^{\mathrm{b}}$ & $0.300^{\mathrm{b}}$ & $56.67^{\mathrm{bc}}$ & $3.87^{\mathrm{c}}$ & $20.27^{\mathrm{a}}$ & 24.12 & $102.7^{\mathrm{c}}$ & $85.33^{\mathrm{c}}$ & $36.67^{\mathrm{a}}$ & 48.96 & $17.07^{\mathrm{e}}$ \\
\hline Pomegranate & $11.33^{\mathrm{b}}$ & $190.7^{\mathrm{b}}$ & $0.333^{\mathrm{b}}$ & $54.33^{\mathrm{cd}}$ & $5.17^{\mathrm{b}}$ & $18.93^{b}$ & 24.63 & $100.7^{\mathrm{c}}$ & $97.86^{\mathrm{b}}$ & $33.02^{b}$ & $48.11^{\mathrm{c}}$ & $19.57^{b}$ \\
\hline Vitamin E & $10.99^{\mathrm{b}}$ & $190.6^{\mathrm{b}}$ & $0.313^{\mathrm{b}}$ & $54.29^{\text {cd }}$ & $5.15^{\mathrm{b}}$ & $18.92^{b}$ & 22.79 & $100.5^{\mathrm{c}}$ & $97.75^{\mathrm{b}}$ & $31.02^{\mathrm{b}}$ & $49.93^{c}$ & $19.55^{\mathrm{b}}$ \\
\hline SEM & 0.638 & 1.15 & 0.030 & 1.44 & 0.126 & 0.343 & 0.075 & 1.545 & 1.146 & 0.680 & 1.930 & 0.229 \\
\hline Prop. & $*$ & $*$ & $*$ & $*$ & $*$ & $*$ & NS & $*$ & $*$ & $*$ & $*$ & $*$ \\
\hline
\end{tabular}

Note. Means with the same letter are not significantly different $(\mathrm{P} \leq 0.05)$.

T1: control(+), T1: control (-), T3: Ziziphus, T4: Jatropha, T5: white berry, T6: black berry, T7: pomegranate leaves extracted meal by $0.50 \mathrm{~g} / \mathrm{kg}$, and T8: Vit. E $0.20 \mathrm{~g} / \mathrm{kg}$.

In addition, results concluded that there were significant decreased in plasma parameters as effect by supplementations of diet with pomegranate (cholesterol, LDL, total lipids, AST, ALT and MDA). The present results are coincide with Yassein et al. (2015) who investigated that the role of Punicagrantum leaves extraction which decreased Plasma cholesterol, LDL, total lipids and MDA. The pomegranate ability to reduction of MDA levels could be explained by antioxidant compounds including, (a) ellagitannins, and a precursor of ellagic acid, which has been found to have antioxidative properties (Mass et al., 1991).

Therefore, it was suggested that the applied supplements may result in a lower MDA content in the skeletal muscle and liver of chickens due to their potential as antioxidants. Another possibility may be the expanded mRNA genes expression encoding antioxidant enzymes such as SOD observed in chicks nourished a phytogenic leaves extracted included-diet.

It was observed that feeding with dietary supplementations (Ziziphus, Jatropha, white and black berry and pomegranate leaves extract) did not alter plasma concentrations of GSH of growing broilers compared with the basal diet groups. But broilers fed diet supplementations exhibited significantly higher blood plasma level of SOD than the control groups. Consistent results might indicate that phytogenic-additions are safe and had useful effect on the metabolic functions or the health status of hybrid chicks, since no morbidity or mortality were reported during the experiment period.

\subsection{Liver Histology}

Histological examination of liver sections from different treatments showed moderate to severe changes associated with dietary supplementations (Ziziphus, Jatropha, white and black berry and pomegranate leaves extracted meal). It is clear from Figures 1 and 2 that the liver of the positive and negative control group were nearly similar except for the presence of some infiltrated fluids. Figure 1 shows enlarged $\mathrm{CV}$ and dilated bile duct (b) with many necrotic areas (n). Similarly, this was the same case for the liver section from the negative control chicks (Figure 2) where marked congested areas (c) accompanied with the presence of many kupffer cells (K) and large lymphocytes (L) indicative of undesirable changes in liver parenchyma. The reason of this case was not clear and it is difficult to attribute it to a specific reason, although this group of chicks had the worst live body weight and weight gain among the other groups. 
An interesting observation was seen in the liver section in Figures 5 and 6 which show a very well histological structure of liver parenchyma with dark stained hepatic cells (h) and few lymphocytes and necrotic areas. This indicates better liver function as also appears from the normal architecture with a normal size central vein (CV) and several homogenous masses of liver cords with normal hepatocytes (h) and few fatty cirrhotic areas (f). It appears from Figure 7 that the liver of the pomegranate treatment showed normal architecture with normal size cv with normal hepatocytes and few fatty cirrhotic areas with the presence of many kupffer cells and some obvious blood sinusoids in liver parenchyma. This was also observed in Figures 3 and 4, although the CV was greatly enlarged and dilated. However, the other hepatic structure appeared normal with obvious blood sinusoids (s) in liver parenchyma. There are also few necrotic, fatty cirrhotic and lymphocytic cells within the hepatic cords. Moreover, Figures 3 and 4 show similar architecture as that of Figure 8 but with an observed hypertrophy of hepatocytes and greatly dilated cv engorged with many erythrocytes. Furthermore, Figure 8 shows normal liver structure and normal arrangement of liver cells within cords but with many fatty cirrhotic areas within the liver tissues with many necrotic areas (n).

Our observations harmonize with Ojediran et al. (2015) who observed histological changes from the hepatic of the hybrid chicks nourished the experimental diets; the hepatocytes ranged from mild to severe degeneration of, an indication of substantial residual toxin in Jatropha. In contrast to this cituation, the liver did not show any pathological alteration or signs of hepatic/ lipidosis in any of the Jatropha treatment (Kumar et al., 2010). In this context, Enver and Mesut (2003) confirmed the influence of $\alpha$-Tocopheryl and selenium in minimizing hepatic damage in glucocorticoid-treated Wistar rats. It has been reported that $\alpha$-Tocopheryl and Se addition can suppress CCl4-induced activation and proliferation of hepatic stellate cells (HSCs) and promote the apoptosis of activated HSCs in acute damage phase (Shen et al., 2005). They also demonstrated that Vit E and Se can also effectively decrease the degree of hepatic fibrosis and stimulate the recovery process.

It is likely that these changes were associated with the type of the dietary supplement and its composition and content from different substance, i.e. phytochemicals, anti-nutritional factors, polyphenols, antioxidants, etc. In this regard, the growth performance results and the plasma biochemical parameters showed better results (performance) of chicks had fed white berry, black berry, pomegranate and Jatropha leaves extracted-supplemented diet, respectively compared with the other treatments.

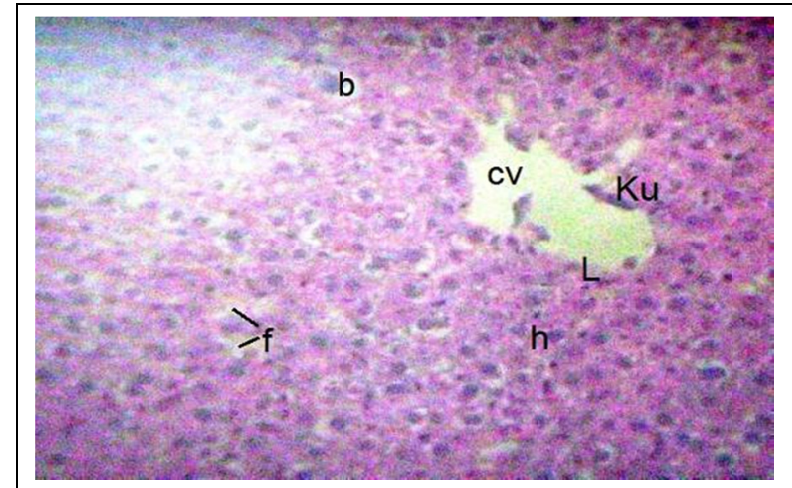

Figure 1

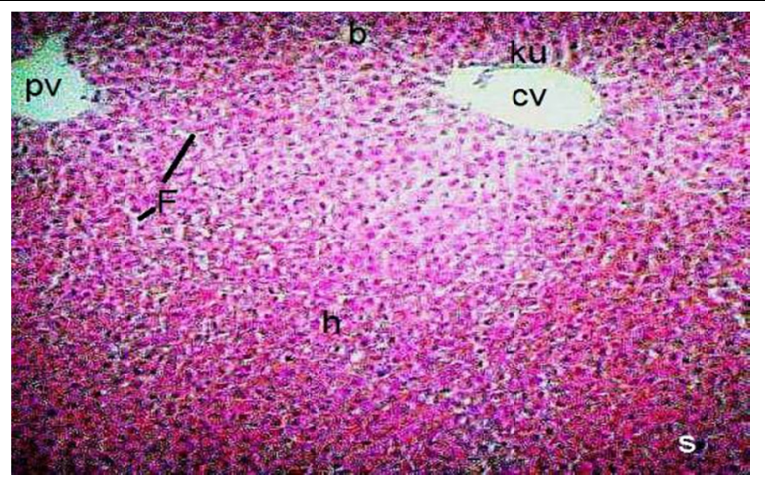

Figure 3

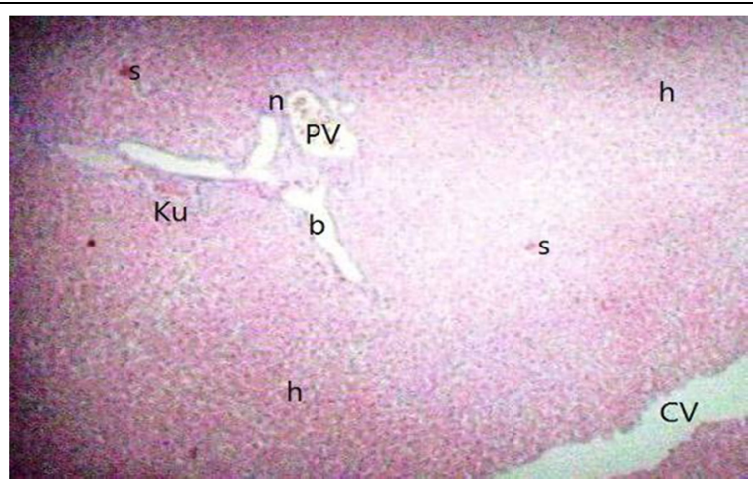

Figure 2

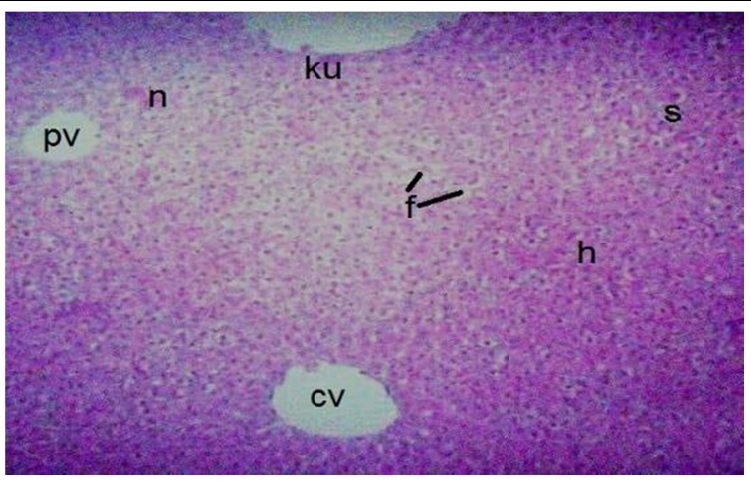

Figure 4 


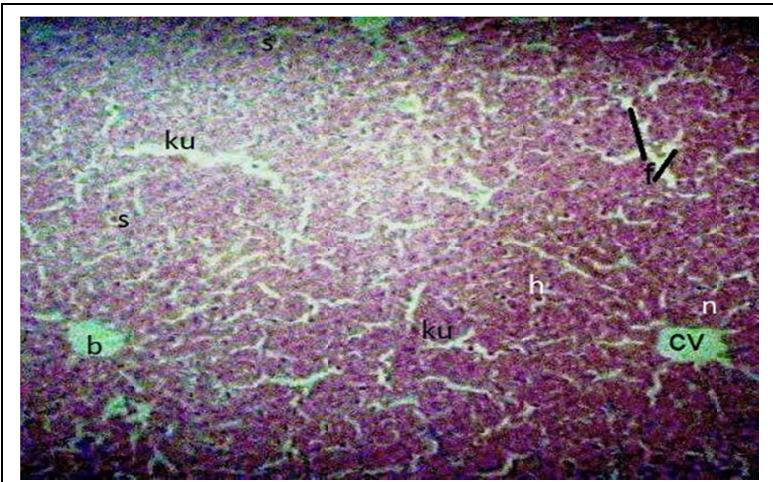

Figure 5

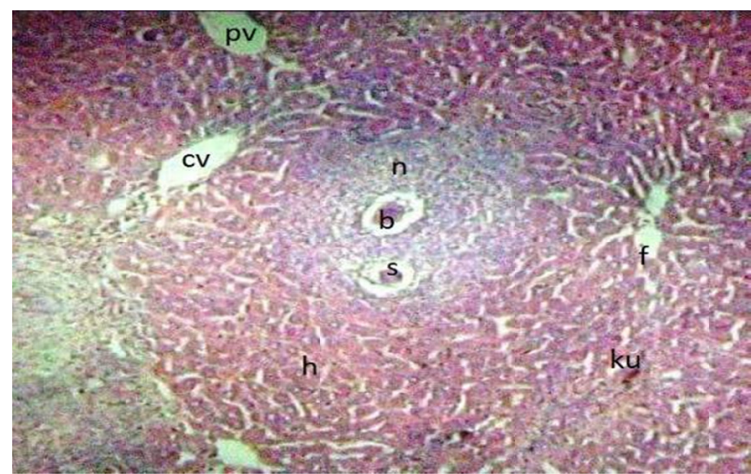

Figure 7

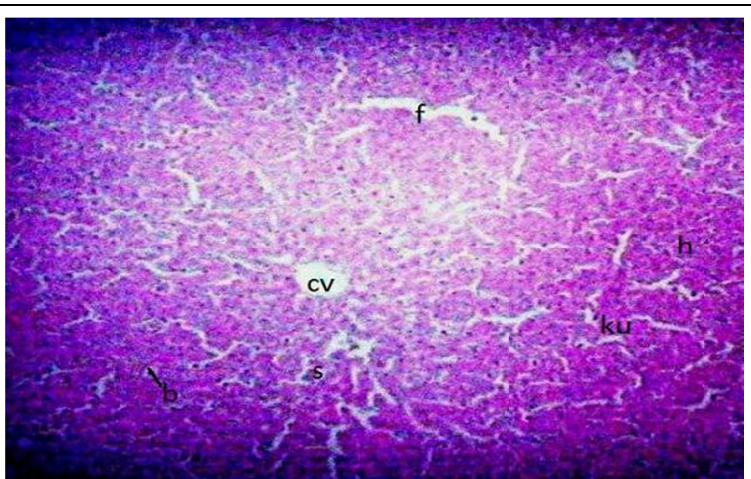

Figure 6

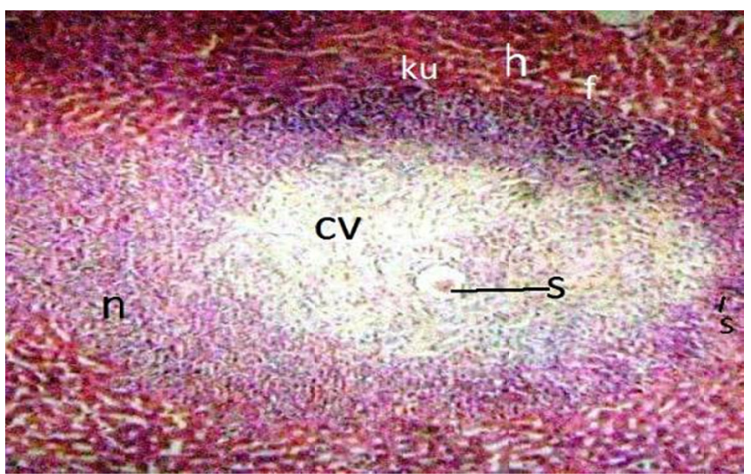

Figure 8

Figure 1. Control(+); Figure 2. Control (-); Figure 3. Ziziphus; Figure 4. Jatropha; Figure 5. White berry; Figure 6. Black berry; Figure 7. Pomegranate leaves extracted meal by $0.50 \mathrm{~g} / \mathrm{kg}$; Figure 8 . Vit. E $0.20 \mathrm{~g} / \mathrm{kg}$

Note. $\mathrm{cv}=$ central vein, $\mathrm{b}=$ bile duct, $\mathrm{f}=$ fatty cirrhotic area, $\mathrm{h}=$ hepatocytes, $\mathrm{n}=$ necrotic area, $\mathrm{ku}=\mathrm{kupffer}$ cells, $\mathrm{p}=$ portal vessel, $\mathrm{L}=$ lymphocytes and $\mathrm{s}=$ blood sinusoids.

\section{Acknowledgements}

We would like acknowledge the faculty stuff for their love, support and friendship. We wish to thank every single one for their love, support and much needed prayers.

\section{References}

Abalaka, M. E., Daniyan, S. Y., \& Mann, A. (2010). Evaluation of the antimicrobial activities of two Ziziphus species (Ziziphus mauritiana L. and Ziziphus spinachristi L.) on some microbial pathogens. African Journal of Pharma and Pharmacology, 4(4), 135-139.

Abd El-Hady, A. M., Elghalid, O. A., \& Elnagar, S. A. (2017). Antioxidative Effect of Dietary Black Mulberry (Morusnigra) Fruit Juice in Muscovy Ducks under High Ambient Tempreature. Egypt. Poult. Sci., 37(3), 815-831.

Abdulameer, Y. S., Husain, F., \& Al-Cekal, S. H. A. (2017). Efficacy of Ziziphus mauritiana leaves extract as antibiotic alternatives in broiler chicken. Journal of Entomology and Zoology Studies, 5(5), 742-746.

Abo El-Maaty, M. H. H., Rabie, M. H., \& EL-Khateeb, A. Y. (2014). Response of Heat-Stressed Broiler Chicks to Dietary Supplementation with Some Commercial Herbs. Asian Journal of Animal and Veterinary Advances, 9(12), 743-755. https://doi.org/10.3923/ajava.2014.743.755

Adeyemo, G. O., \& Oluyede1, F. A. (2015). Dietary Inclusion of Ethanolic Extracts of Jatropha curcas on the Performance and Carcass Characteristics of Broiler Chickens. American Journal of Experimental Agriculture, 8(2), 130-136. https://doi.org/10.9734/AJEA/2015/10580

Al-Kirshi, R. A., Alimon, A. R., Zulkifli, I., Sazili, A. Q., Zahari, W. M., \& Ivan, M. (2010). Utilization of mulberry leaf meal (Morus alba) as protein supplement in diets for laying hens. Italy Journal of Animal Science, 9(51), 265-267. https://doi.org/10.4081/ijas.2010.e51 
Ao, X., Yan, L., Meng, Q. W., Zhou, T. X., Wang, J. P., Kim, H. J., ... Kim, I. H. (2011). Effects of Saururus chinensis extract supplementation on growth performance, meat quality and slurry noxious gas emission in finishing pigs. Livest. Sci., 138, 187-192. https://doi.org/10.1016/j.livsci.2010.12.029

AOAC (Association of Official Analytical Chemists). (2000). Official Methods of Analysis (17th ed.). Washington, DC.

Arshad, M. S., Anjum, F. M., Khan, M. I., Shahid, M., Akhtar, S., \& Sohaib, M. (2013). Wheat germ oil enrichment in broiler feed with $\alpha$-lipoic acid to enhance the antioxidant potential and lipid stability of meat. Lipids in Health and Disease, 12(1), 164. https://doi.org/10.1186/1476-511X-12-164

Atamgba, A. A., Margaret, A. A., Kayoed, D., \& Amonor, J. W. (2015). The biomedical significance of the phytochemical, proximate and mineral composition of the leaf, stembark and root of Jatropha curcas. Asian Pac. J. Trop. Biomed., 2015, 650-657. https://doi.org/10.1016/j.apjtb.2015.05.015

Bartles, H., Bohmer, M., \& Heierli, C. (1972). Serum creatinine determination without protein precipitation. Clin. Chim. Acta, 37, 193-197.

Bartov, I., \& Frigg, M. (1992). Effect of high concentrations of dietary vitamin E during various age periods on performance, plasma vitamin $\mathrm{E}$ and meat stability of broiler chicks at 7 weeks of age. Br. Poult. Sci., 33, 393-402. https://doi.org/10.1080/00071669208417477

Beutler, E., Duron, O., \& Kefly, B. M. (1963). Improved method for the determination of blood glutathione. J. Lab. Clin. Med., 61, 882-888.

Biswas, A., Ahmed, M., Bharti, V., \& Singh, S. (2011). Effect of antioxidants on physio-biochemical and hematological parameters in broiler chickens at high altitude. Asian-Aust. J. Anim. Sci., 24, $246-249$. https://doi.org/10.5713/ajas.2011.10060

Cai, L. W., \& Ramanatha, S. (2012). Potential anti radical activity and cyto toxicity assessment of Ziziphus maritiana and Syzygium polyanthum. International Journal of Pharmacology, 8(10), 535-541.

Conti, M., Mordand, P. C., Levillain, P., \& Lemonnier, A. (1991). Improved Fluorometric Determination of Malondialdehyde. Clin. Chem., 37(7), 1273-1275.

Dale, N. (2007). Biocombustibles y producción avícola. Ind. Avic. Marzo, 19-21.

Dei, H. K., Rose, S. P., Mackenzie, A. M., \& Amarowicz, R. (2008). Growth performance of broiler chickens fed diets containing shea nut (Vitellaria paradoxa, Gaertn.) meal fermented with Aspergillus niger. Poult. Sci., 87, 1773-1778. https://doi.org/10.3382/ps.2008-00055

Devi, B., Sharma, N., Kumar, D., \& Jeet, K. (2013). Morus alba Linn: A Phytopharmacological Review. International Journal of Pharmacy and Pharmaceutical Sciences, 5(2), 14-18.

Duncan, D. B. (1955). Multiple range and multiple F tests. Biometrics, 11, 1-42. https://doi.org/10.2307/3001478

El-Bendary, M. A., Hamed, H. A., \& Moharam, M. E. (2016). Potential of Bacillus isolates as bio-control agents against some fungal phytopathogens. Biocatal. Agric. Biotechnol., 5, 173-178. https://doi.org/10.1016/ j.bcab.2016.02.001

Englmaierová, M., Bubancová, I., Vít, T., \& Skřivan, M. (2011). The effect of lycopene and vitamin E on growth performance, quality and oxidative stability of chicken leg meat. Czech J. Anim. Sci., 56(12), 536-543. https://doi.org/10.17221/4416-CJAS

Enver, B., \& Mesut, A. (2003). Effects of dietary vitamin E and selenium on antioxidative defense mechanisms in the liver of Wistar rats treated with high doses of glucocorticoid. Biological Trace Element Research, 91, 231-241. https://doi.org/10.1385/BTER:91:3:231

Erf, G. F., Bottje, W. G., Bersi, T. K., Headrick, M. D., \& Fritts, C. A. (1998). Effects of dietary vitamin E on the immune system in broilers: Altered proportions of CD4 T cells in the thymus and spleen. Poult. Sci., 77, 529-537. https://doi.org/10.1093/ps/77.4.529

George, O. S., Wariboko, O. N., \& Nwachukwu, C. (2016). Effect of Jatropha curcas as Feed Additive on Growth Performance and Carcass Characteristic of Weaned Rabbit. Adv. Agric. Biol., 4(4), 82-85. https://doi.org/10.15192/PSCP.AAB.2016.5.4.8285

Gil, M. I., Tomás-Barberán, F. A., Hess-Pierce, B., Holcroft, D. M., \& Kader, A. A. (2000). Antioxidant activity of pomegranate juice and its relationship with phenolic composition and processing. J. Agric. Food Chem., 48(10), 4581-4589. https://doi.org/10.1021/jf000404a 
Hamid, A. A., Oguntoye, S. O., Alli, S. O., Akomolafe, G. A., Aderinto, A., Otitigbe, A., ... Aminu, R. O. (2016). Chemical composition, antimicrobial and free radical scavenging activities of Grewia pubescens. Chem. Int. 2, 254-261.

Hassan, S. M., Sultana, B., Iqbal, M., \& Naz, S. (2017). Biological approach to aflatoxin control in stored poultry feed. Acta Veterinaria Brno, 86(1), 19-28.https://doi.org/10.2754/avb201786010019

Hasso, R. A. (2009). Histological Toxic Effect of Nandrolone Decanoate on the Kidney of Male Rabbit. The Medical Journal of Basrah University, 2(1), 1-4.

Hernandez, F., Madrid, J., Garcia, V., Orengo, J., \& Megias, M. D. (2004). Influence of two plant extracts on broilers performance, digestibility and digestive organ size. Poult. Sci., 83, 169-174. https://doi.org/ $10.1093 / \mathrm{ps} / 83.2 .169$

Ibrahim, M. R., El-Latif, M. S. A., \& El-Yamany, A. T. (1998). Effect of adding some natural growth promoters to broiler chicks diets on growth performance, digestibility and some metabolic function. J. Agric. Sci., 32, 1029-1037.

Islam, M. R., Nurealam Siddiqui, M., Khatun, A., Siddiky, M. N. A., Rahman, M. Z., Bostami, A. B. M., \& Selim, A. S. M. (2014). Dietary Effect of Mulberry Leaf (Morus alba) Meal on Growth Performance and Serum Cholesterol Level of Broiler Chickens. SAARC J. Agri., 12(2), 79-89. https://doi.org/10.3329/ sja.v12i2.21920

Johnson, O. R., Iye, O. P., Dwana, K. G., \& Emmanuel, T. (2013). Effect of Jatropha curcas Supplemented Diet on Broilers. Sch. Acad. J. Biosci., 1(6), 329-336.

Khan, Z., Bhadouria, P., \& Bisen, P. S. (2005). Nutritional and therapeutic potential of Spirulina. Current Pharma Biotechnol, 6(5), 373-379. https://doi.org/10.2174/138920105774370607

Knekt, P., Aromaa, P., \& Maateta, J. (1991). Vitamin E and cancer prevention. American Journal of Clinical Nutrition, 53, 283-286. https://doi.org/10.1093/ajcn/53.1.283S

Kumar, V., Makkar, H. P. S., Amselgruber, W., \& Becker, K. (2010). Physiological, Haematological and Histopathological Responses in Common Carp (Cyprinus carpio L.) Fingerlings Fed with Differently Detoxified Jatropha curcas Kernel Meal. Food Chem. Toxicol., 48(8-9), 2063-2072. https://doi.org/ 10.1016/j.fct.2010.05.007

Langhout, P. (2000). New Additives for Broiler Chickens. World Poult., 16, 22-27.

Lin, Y. F., Chang, S. J., Yang, J. R., Lee, Y. P., \& Hsu, A. L. (2005b). Effects of supplemental vitamin E during the mature period on the reproduction performance of Taiwan Native Chicken cockerels. Br. Poult. Sci., 46, 366-373. https://doi.org/10.1080/00071660500098186

Lin, Y. F., Tsai, H. L., Lee, Y. C., \& Chang, W. S. J. (2005a). Maternal vitamin E supplementation affects the antioxidant capability and oxidative status of hatching chicks. J. Nutr., 135, 2457-2461. https://doi.org/ $10.1093 / \mathrm{jn} / 135.10 .2457$

Martínez, Y., Martínez, O., Valdivié, M., Betancur, C., Córdova, J., \& Godoy, M. (2011). Effect of squash seed (Cucurbita moschata) meal on broiler performance, sensory meat quality and blood lipid profile. Brazilian J. Poult. Sci., 13(4), 219-226.

Mass, J. L., Galletta, G. L., \& Stoner, G. D. (1991). Ellagic acid, an anticarcinogen in fruits, especially in strawberries. Hort. Sci., 26, 10-14.

Mohebbi, A., Khaki, Z., Asadi, F., Pourkabir, M., \& Modirsanei, M. (2007). Effect of Mulberry (Morus alba L.) Leaves Extract on the Secretion and Content of Triglyceride in the Chicken Hepatocytes Primary Culture. International Journal of Pharmacology, 3, 116-119. https://doi.org/10.3923/ijp.2007.116.119

Morrissey, P. A., Buckley, D. J., Sheehy, P. J. A., \& Monahan, F. J. (1994). Vitamin E and meat quality. Proc. Nutr. Soc., 53, 289-295. https://doi.org/10.1079/PNS19940034

NRC (National Research Council). (1994). Nutrient Requirements of Poultry (9th ed.). National Academy Press, Washington, DC., USA.

Odoemelam, V. U., Nwaogu, K. O., Ukachukwu, S. N., Etuk, E. B., Etuk, I. F., Aladi, N. O., \& Ogbuewu, I. P. (2013). Growth Response, Carcass Quality and Organoleptic Assessment of Broiler Chickens Fed Ocimum gratissimum L. Supplemented Diets. Int'l Journal of Agric and Rural Dev., 16(2), 1521-1528. 
Ojediran, T. K., Alamu, D., Olayeni, T., \& Emiola, A. (2015). Hepatic histology of broiler chicks fed differently processed Jatropha curcas kernel meals. Global Journal of Animal Scientific Research, 3(4).

Ojewola, G. S., Okoye, F. C., \& Ukoha, O. A. (2005). Comparative utilization of three animal protein sources by broiler chickens. International Journal of Poultry Science, 4970, 462-467.

Okoko, T., \& Oruambo, I. F. (2008). The effects of Hibiscus sabdariffa calyx on cisplatin-induced tissues damaged in rats. Biokemistri, 20(2), 47-52.

Panja, P. (2013). The Effects of Dietary Mulberry Leaves (Morus alba L.) on Chicken Performance, Carcass, Egg Quality and Cholesterol Content of Meat and Egg. Walailak Journal of Science \& Technology, 10(2), 121-129.

Patton, C. J., \& Crouch, S. R. (1977). Spectrophotometric and kinetics investigation of the Berthelot reaction for the determination of ammonia. Analytical Chemistry, 49, 464-469. https://doi.org/10.1021/ac50011a034

Perez, T. I., Zuidhof, M. J., Renema, R. A., Curtis, J. M., Ren, Y., \& Betti, M. (2010). Effects of vitamin E and organic selenium on oxidative stability of $\omega-3$ enriched dark chicken meat during cooking. Journal of Food Science, 75, 25-34. https://doi.org/10.1111/j.1750-3841.2009.01478.x

Reddy, M. K., Gupta, S. K., Jacob, M. R., Khan, S. I., \& Ferreira, D. (2007). Antioxidant, antimalarial and antimicrobial activities of tannin-rich fractions, ellagitannins and phenolic acids from Punica granatum L. PlantaMedica, 73, 461-467. https://doi.org/10.1055/s-2007-967167

Reitman, S., \& Frankel, S. (1957). A colorimetric method for the determination of serum glutamic oxaloacetic and glutamic pyruvic transaminases. Amer. J. Clin. Pathol., 28, 56-63. https://doi.org/10.1093/ajcp/28.1.56

Rezaeipour, V., Mosaei, M., \& Irani, M. (2011). Effects of dietary alpha tocopherol acetate and soybean oil on growth performance and meat oxidative stability of broiler chicks. J. Cell Anim. Biol., 5(12), 271-274.

Richmond, W. (1973). Cholesterol enzymatic colorimetric test chop-PAP method of estimation of total cholesterol in serum. Clin. Chem., 191, 1350-1356.

Roa, M. L. (2011). Chickens fed with different levels of flour Erythrina poeppigiana and flour Trichanthera gigantean. Rev. Sist. Prod. Agroecol., 2, 22.

Sahin, K., Onderci, M. C., Sahin, N., Gursu, M. F., \& Kucuk, O. (2006). Effects of lycopene supplementation on antioxidant status, oxidative stress, performance and carcass characteristics in heat-stressed Japanese quail. Journal of Thermal Biology, 31, 307-312. https://doi.org/10.1016/j.jtherbio.2005.12.006

Saleh, H., Golian, A., Kermanshahi, H., \& Mirakzehi, H. T. (2017). Effects of dietary $\alpha$-tocopherol acetate, pomegranate peel, and pomegranate peel extract on phenolic content, fatty acid composition, and meat quality of broiler chickens. Journal of Applied Animal Research, 45(1), 629-636. https://doi.org/ 10.1080/09712119.2016.1248841

Sarita, S., Rashmi, K., Anju, T., \& Rajesh, P. (2006). Nutritional quality of leaves of some geno types of mulberry (Morus alba). Int. J. Food Sci. Nutr., 57, 305-313. https://doi.org/10.1080/09637480600801837

SAS Institute. (2006). SAS ${ }^{\circledR}$ User's Guide for personal computer. SAS Institute Inc., Cary, NC. USA.

Seeram, N. P., Adams, L. S., Henning, S. M., Niu, Y., Zhang, Y., Nair, M. G., \& Heber, D. (2005). In vitro Antiproliferative, Apoptotic and Antioxidant Activities of Punicalagin, Ellagic acid and a Total Pomegranate Tannin Extract are Enhanced in Combination with Other Polyphenols as Found in Pomegranate Juice. $J$. Nutri. Biochem., 16(6), 360-367. Retrieved from https://escholarship.org/uc/item/7mn5j20t

Serrano, J., Puupponen-Pimiä, R., Dauer, A., Aura, A. M., \& Saura-Calixto, F. (2009). Tannins: current knowledge of food sources, intake, bioavailability and biological effects. Molecular Nutri. and Food Research, 53(S2), S310-S329. https://doi.org/10.1002/mnfr.200900039

Seyoum, A., Asres, K., \& Kandeel El-Fiky, F. (2006). Structure-Radical Scavenging Activity Relationships of Flavonoids. Phytochemistry, 67, 2058-2070.

Sharifi, S. D., Khorsandi, S. H., Khadem, A. A., Salehi, A., \& Moslehi, H. (2013). The effect of four medicinal plants on the performance, blood biochemical traits and ileal microflora of broiler chicks. Veterinarski Arhiv., 83(1), 69-80.

Shen, X. H., Cheng, W. F., Li, X. H., Sun, J. Q., Li, F., Ma, L., \& Xie, L. M. (2005). Effects of dietary supplementation with vitamin E and selenium on rat hepatic stellate cell apoptosis. World J. Gastroenterol, 11(32), 4957-4961. https://doi.org/10.3748/wjg.v11.i32.4957 
Shivakumar, G. R., Anatha Raman, K. V., Magadum, S. B., \& Datta, R. K. (1995). Medicinal value of Mulberry. Ind. Silk, 34, 15-16.

Siegel, P. B., Price, S. E., Meldrum, B., Picard, M., \& Geraert, P. A. (2001). Performance of Pureline Broiler Breeders Fed Two Levels of Vitamin E. Poult. Sci., 80, 1258-1262. https://doi.org/10.1093/ps/80.9.1258

Singh, B., \& Makkar, H. P. S. (2002). The potential of mulberry foliage as a feed supplement in India. In M. D. Sanchez (Ed.), Mulberry for Animal Production (FAO Animal and Health Production Paper 147, pp. 139-156). FAO, Rome.

Son, J. H. (2014). Effects of Dietary Ziziphus jujuba Seed Meal on Broiler Performance. Korean Journal of Poultry Science, 4l(4), 279-285. https://doi.org/10.5536/KJPS.2014.41.4.279

Sun, Y., Oberley, L. W., \& Ying Li (1988). A Simple method for clinical assay of superoxide dismutase. Clin Chem., 3413, 497-500.

Valacchi, G., Belmonte, G., Miracco, C., Eo, H., \& Lim, Y. (2014). Effect of combined mulberry leaf and fruit extract on liver and skin cholesterol transporters in high fat diet-induced obese mice. Nutrition Research and Practice, 8(1), 20-26. https://doi.org/10.4162/nrp.2014.8.1.20

Vasanthakumar, P., Sasikumar, P., Pangayarselvi, B., Chandrasekaran, D., Doraisamy, K. A., Senthilkumar, S., \& Purushothaman, M. R. (2013). Performance of broiler chicken fed tulsi leaf powder and leaf extract supplemented diets during summer to alleviate heat stress. Indian Journal of Animal Sciences, 83(9), 930-931.

Wang, C., Yang, F., Wang, Q., Zhou, X., Xie, M., Kang, P., ... Peng, X. (2017). Nutritive Value of Mulberry Leaf Meal and its Effect on the Performance of 35-70-Day-Old Geese. J. Poult. Sci., 54, 41-46. https://doi.org/ 10.2141/jpsa.0160070

Yang, N. C., Jhou, K. Y., \& Tseng, C. Y. (2012). Antihypertensive effect of mulberry leaf aqueous extract containing c-aminobutyric acid in spontaneously hypertensive rats. Food Chemistry, 132, 1796-1801. https://doi.org/10.1016/j.foodchem.2011.11.143

Yassein, D. M. M., Abdallah, E. A., Ismail, I. I., \& Faddle, A. A. (2015). Effect of Dietary Supplementation of Pomegranate Peel Powder and Butylated Hydroxy Toluene on Some Productive Physiological and Immunological Parameters of Japanes Quail. Egyptian J. Anim. Prod., 52(Suppl.), 105-113.

Zeni, A. L. B., \& Molin, M. D. (2010). Hypotriglyceridemic effect of Morus alba L., Moraceae, leaves in hyperlipidemic rats. Brazilian Journal of Pharmacognasy, 20(1), 130-133. https://doi.org/10.1590/ S0102-695X2010000100025

\section{Copyrights}

Copyright for this article is retained by the author(s), with first publication rights granted to the journal.

This is an open-access article distributed under the terms and conditions of the Creative Commons Attribution license (http://creativecommons.org/licenses/by/4.0/). 